\title{
OPTIMISATION OF THE OPERATION REGIMES FOR THE WATER- BASED CONDENSATION PARTICLE COUNTER
}

\author{
G. Mordas ${ }^{a}$, T. Petäjä ${ }^{b}$, and V. Ulevičius ${ }^{a}$ \\ a State Research Institute Center for Physical Sciences and Technology, Savanoriu 231, LT-02300 Vilnius, Lithuania \\ E-mail:genrik@ftmc.lt \\ ${ }^{\mathrm{b}}$ Department of Physical Sciences, University of Helsinki, P. O. Box 64, 00014 Helsinki, Finland
}

Received 19 July 2012; revised 10 September 2012; accepted 20 September 2012

\begin{abstract}
A water-based condensation particle counter (CPC) TSI 3785 is a new step for the ultrafine particle measurement technique. A new instrument was examined in this study. Detection efficiency was investigated experimentally using different temperatures of the saturator and of the growth tube. The experiments showed that detection efficiency can be improved by increasing the temperature of the growth tube and decreasing the saturator temperature. Fitting a two-free parameter equation to the experimental data, the cut-sizes $D_{50 \%}$ were determined. The determined cut-sizes were comparable with the other three widely used fitting equations. The cut-sizes were studied by changing the growth tube temperature from 40 to $65^{\circ} \mathrm{C}$ and varying the saturator temperature from 10 to $30^{\circ} \mathrm{C}$. For the purpose of the study, the instrument operation regime (saturator and growth tube temperatures) can be optimised by selecting the needed cut-size. The cut-sizes can be changed in a wide range. The smallest detected cut-size $D_{50 \%}$ was $4.2 \mathrm{~nm}$, and the largest $14.6 \mathrm{~nm}$. In the default operation regime, the instrument cut-size was $5.9 \mathrm{~nm}$. The detection efficiency of the studied TSI CPC 3785 was compared with the ultrafine TSI CPC 3786. The results showed that the studied CPC can be optimised to the regime having a smaller cut-size than the cut-size of the ultrafine CPC in the default regime. Thus, the tested TSI CPC 3785 had the lowest detection limit $\left(D_{50 \%}\right)$ of $4.2 \mathrm{~nm}$, and the TSI CPC 3786 had $4.6 \mathrm{~nm}$ for the silver particles.
\end{abstract}

Keywords: detection efficiency, condensation particle counter, ultrafine particles

PACS: 92.60.MZ, 92.20.Bk

\section{Introduction}

Atmospheric aerosol particles influence the Earth's radiation balance directly by scattering and absorbing solar radiation and indirectly by acting as cloud condensation nuclei. This influence depends on the aerosol particle size, which ranges from one nanometre (ultrafine particles) to a hundred of micrometres (coarse particles). The smallest ultrafine particles make up a nucleation mode. They are formed from the gas phase by homogeneous, heterogeneous, and ion-induced nucleation [1]. Then condensation and coagulation processes increase the smallest particles forming Aitken, accumulation and coarse particle modes. The nucleation mode particles and the nucleation can play a decisive role in regulating the particle size distribution in the atmosphere. Thus, ultrafine particles have an indirect effect on the global climate [2] and on human health [3].
The most available ultrafine particle detectors are condensation particle counters (CPCs). The operating principle of the CPC consists of three processes: 1) supersaturating working fluids, 2) growing of the particle by condensation of supersaturated vapours, and 3) optical detection of the particles after their increase in size. The technique of creating vapour supersaturation classifies the condensation particle counters into types. There are three types of CPCs: adiabatic expansion [ [4], conductive cooling [5], and a mixing-type [6]. The CPCs of all types and their creative history have recently been reviewed by McMurry [ The type of a CPC and its construction determine the performance characteristics of the device [8].

The general characteristic of the condensation particle counters is the detection efficiency as a function of the particle size, or a more practical parameter is a cut-size. It is a diameter at which detection efficiency drops to $50 \%\left(D_{50 \%}\right)$. The cut-size depends 
on aerosol losses in the inlet of the CPC, the efficiency of the optical system, and the particle activation efficiency. However, Stoltzenburg and McMurry [5] have shown that the cut-size is mostly a function of the activation efficiency alone. Thus, for a conductive cooling CPC, it can be determined by the difference of temperatures between the saturator and the condenser [9].

There are several widely used commercial CPCs. They are alcohol-based instruments. Usually, they use butanol or propanol. However, in the recent years a water-based CPC has appeared. It is designed and described by Hering and Stoltzenburg [10]. The first commercial model is called TSI CPC 3785 [1]. It has a unique design that allows water to be a working material for the particle amplification in the device. The pure water is not dangerous to the environment and human health compared with other CPCs using butanol or propanol. Thus, a new water-based CPC can find a very wide use in many different applications of human activities which need nanometre particle measurements.

In this study the particle detection efficiency of the TSI CPC 3785 was experimentally investigated in the 3-20 nm particle diameter range. The cut-size was determined by four fitting mathematical functions to the empirical data. The measurements were made for different operation regimes of the CPC. The operation regimes were changed by varying the temperature of the saturator and of the growth tube. The operation regime of the TSI CPC 3785 was compared with the ultrafine TSI CPC 3786.

\section{Methods}

The method described by Scheibel and Porstendörfer [12] to determine the particle detection efficiency was used to study the particle detection efficiency of a new CPC in this work (Fig. 1). Aerosol particles generated in gas by heating bulk material with a tube furnace and further cooling formed by the nucleation of the produced vapours. The size and number concentration of the produced particles depend on the evaporated material, heating and cooling temperatures, and the flow rate through the furnace. In this study, silver has been used as the particle material. Silver particles formed in the nitrogen atmosphere. The flow rate of nitrogen passing through the tube was set at $3.2 \mathrm{~L} / \mathrm{min}$. The furnace temperature was varied between 1000 and $1100{ }^{\circ} \mathrm{C}$. The polydisperse aerosol formed in the tube was charged with the ${ }^{241} \mathrm{Am}$ bipolar charger and classified using a differential mobility analyser (DMA VIE-08, Hauke short). The DMA was operated using the aerosol flow rate of $2.0 \mathrm{~L} / \mathrm{min}$ and the sheath and excess air flow rates of $20.0 \mathrm{~L} /$ min. The excited monodisperse aerosol was diluted to reduce the aerosol concentration below $10^{4} \mathrm{~cm}^{-3}$. In this way, the coincidence error in the concentration determination did not exceed $2 \%$. The diluted sample was divided to the TSI CPC 3785 and TSI aerosol electrometer 3068 . The flow rate of the TSI CPC 3785 was $1.035 \mathrm{~L} / \mathrm{min}$ and of the electrometer $3.710 \mathrm{~L} / \mathrm{min}$. All flows in the experimental setup were controlled using needle valves. The calibration of flows was done using a bubble flow metre.

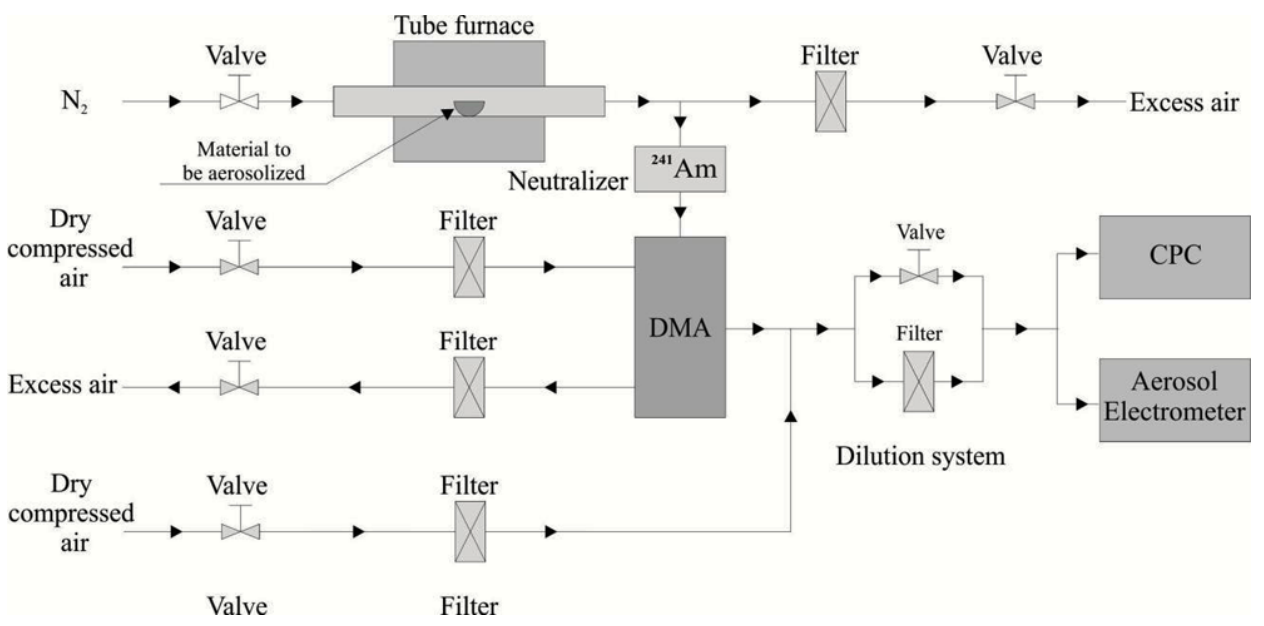

Fig. 1. Experimental set-up for determining the particle detection efficiency of the CPC. The set-up is based on the standardised CPC calibration method described by Scheibel and Porstendörfer [12]. 
The instrument cut-size is determined by fitting the mathematical equation to the measured detection efficiency. In references [5, 10, 13] several fitting equations were presented.

Mertes et al. [13] proposed a four-parameter exponential equation to fit the measured detection efficiency $(\eta)$ of the TSI CPC 3010 . Their equation has the following form:

$$
\begin{array}{ll}
\eta\left(D_{\mathrm{p}}\right)=b-a \cdot\left(1+\mathrm{e}^{\left(D_{\mathrm{p}}-D_{1}\right) / D_{2}}\right)^{-1}, & D_{\mathrm{p}} \geq D_{0}, \\
\eta\left(D_{\mathrm{p}}\right)=0, & D_{\mathrm{p}}<D_{0},
\end{array}
$$

where $D_{\mathrm{p}}$ is a diameter of the measured particles. The free fit parameters are $a, b, D_{1}$, and $D_{2}$. Parameter $D_{0}$ determines the critical particle size, i. e. the particles smaller than the critical particle size are not detected with the instrument and detection efficiency is equal to zero. It is calculated using free fit parameters:

$$
D_{0}=D_{2} \ln \left(\frac{b}{a-1}\right)+D_{1} \text {. }
$$

Later, this expression was used by Wiedensohler et al. [14] to fit the measured detection efficiency of several TSI CPCs $(3010,3760$, and 7620). New modified TSI models, based on the same technology as the TSI CPC 3010, were investigated by Banse et al. [15] using the same four-parameter fit. A comparable equation, but with three free parameters, was described by Hämeri et al. [16] to determine a detection efficiency curve of the propanol-based hand-held TSI CPC 3007.

Studying the detection efficiency of the first ultrafine TSI CPC 3025, Stolzenburg and McMurry [5] described another equation:

$$
\eta\left(D_{\mathrm{p}}\right)=1-\mathrm{e}^{-\ln 2 \cdot\left(D_{\mathrm{p}}-D_{0}\right) /\left(D_{50 \%}-D_{0}\right)},
$$

where the $D_{0}$ determines the critical particle size. The cut-size $\left(D_{50 \%}\right)$ describes the particle size when the particle detection efficiency is 50\% [5]. Additionally, this equation is supplemented with the value of the particle diffusion losses. However, diffusion losses can be calculated only knowing the inner geometry of the particular CPC. For the first time, it was used for the TSI CPC 3025. Later, this equation was applied to study the cut-sizes of other CPCs [17].

Starting the work with water-based CPCs, Hering and Stolzenburg [10] proposed a new equation:

$$
\eta\left(D_{\mathrm{p}}\right)=\left(1-\frac{a}{D_{\mathrm{p}} \ln D_{\mathrm{p}}}\right)\left(1-\mathrm{e}^{\frac{\left(D_{0}-D_{\mathrm{p}}\right)}{D_{1}}}\right) .
$$

Thus, these are many different equations to describe the detection efficiency of CPCs. They were used by different researchers and all of them coincided with the experimental data relatively well. However, all these equations have many freeparameter functions. It presents difficulties to understand their physical determination. Thus, Mordas et al. [18] minimised the number of the free parameters and described a new equation where there are only two free parameters:

$$
\eta\left(D_{\mathrm{p}}\right)=1-\mathrm{e}^{\left(\alpha_{1}-D_{\mathrm{p}}\right) / \alpha_{2}},
$$

where $\alpha_{1}$ and $\alpha_{2}$ are the fitted parameters.

The functional dependence of the main parameters is comparable in all equations. However, the free parameters are strongly described and they are obtained separately for each case. As a result, the slopes of different fitting are not the same. In this work, we compared all four equations and selected one of them to calculate the instrument cut-sizes.

Uncertainties in the determined cut-sizes are a result of DMA sizing errors, inaccuracy of the DMA flows, and counting errors of both the electrometer and the WCPC. The sizing error of the DMA (half width of the transfer function) with the flow rates used in this study corresponds to $0.3 \mathrm{~nm}$. The inaccuracy in the DMA flows introduced errors smaller than 2\%. Moreover, according to the device manual [11], the particle counting accuracy (below $100000 \mathrm{~cm}^{-3}$ ) is $12 \%$ before considering counting statistics. For particle concentrations employed in these studies $\left(>1000 \mathrm{~cm}^{-3}\right)$ the counting statistics do not make a sense for larger particles. A minor effect of counting statistics arises in the smallest size range, where the CPC detects only a small fraction of particles, but this error is less than one per cent of detection efficiency. The uncertainty in the reference electrometer concentration data depends on the accuracy of the voltage monitor and the measurement of the flow rate. With the particle concentrations used in this study, the absolute accuracy of the reference electrometer varied from 5 up to $9 \%$ for the concentrations of 10000 and $2000 \mathrm{~cm}^{-3}$, respectively. 


\section{Results and discussions}

\subsection{Particle detection efficiency of the water-based CPC}

The detection of the nanometre particles is based on the condensation of the working material on the particles, their subsequent growth to the micrometre sizes and then the particle optical detection. It is the main idea of all alcohol-based condensation particle counters. The same idea is used in the water-based TSI CPC 3785. However, the realisation and the used physical processes are different. The size of the sampled aerosol particles is amplified by water condensation in the TSI CPC 3785 [10]. Particle laden sample air is first conditioned to almost $100 \%$ relative humidity with a wetted wick. The working temperature of this saturator is $20^{\circ} \mathrm{C}$ in the default regime. The aerosol particles exit the saturator with the fixed temperature and fully water-saturated air. The actual size enhancement of the sampled aerosol particles occurs in the growth tube, in which the wick is kept wetted but the temperature is increased to $60{ }^{\circ} \mathrm{C}$ [19]. Close to the wick, the partial pressure of water vapour is close to the equilibrium vapour pressure at the wick temperature. As the passing flow in the growth tube has a lower partial pressure of water vapour, diffusion of water vapour takes place toward the centreline of the sample flow. Since mass diffusivity of water vapour is higher than the thermal diffusivity of the air, the region of supersaturation with respect to water vapour is generated in the centre of the growth tube [10]. A high supersaturation level allows us to start the condensation process of water on the particles and on the walls of the growth tube. However, the walls of the growth tube consist of a wet wick, and the saturation level is close one near the wick border. Thus, water condensation is concentrated on the particles and it leads to a greater-size amplification and lower cut-off sizes of the CPC [10].

The key parameters determining the amount of supersaturation obtained within the growth tube are the growth tube and the saturator temperatures. The effect of each temperature on the detection efficiency of the CPC was investigated in our study. For that, we fixed the saturator temperature at $15^{\circ} \mathrm{C}$ and we changed the growth tube temperature from 40 to $65{ }^{\circ} \mathrm{C}$. The experimental results are presented in Fig. 2. They show that when the saturator temperature was $15^{\circ} \mathrm{C}$ and the growth tube temperature was $40{ }^{\circ} \mathrm{C}$, the determined cut-size $D_{50 \%}$ was $10.0 \mathrm{~nm}$.
With the growth tube temperature increasing, the evaporated water molecule concentration close to the wet wick increased as well. Then, the water molecule diffusion gradient increased much more than the temperature gradient to the centreline; as a result the value of supersaturation became higher. The region of supersaturation increased geometrically as well. Subsequently, the detection efficiency curve shifted to smaller sizes. Therewith, the curve slope was straighter. It can be explained by the geometry of the formed supersaturation region inside the growth tube.

Alternative experiments were performed when the growth tube temperature was constant and the saturator temperature was varied. Then, the growth tube temperature was fixed at $65^{\circ} \mathrm{C}$ and the saturator temperature was changed from 10 to $30^{\circ} \mathrm{C}$. The experimental results are presented in Fig. 3. In these experiment series, there was a situation when the coming aerosol was heated or cooled. It was determined that when the flow was heated to $30^{\circ} \mathrm{C}$ and humidified to $100 \%$, the particle detection efficiency was limited. Having the temperature of $65^{\circ} \mathrm{C}$ of the growth tube and $30{ }^{\circ} \mathrm{C}$ of the saturator, the determined cut-size was $7.5 \mathrm{~nm}$. However, by cooling the flow to $10^{\circ} \mathrm{C}$ and humidifying it to $100 \%$, the cut-size was $4.2 \mathrm{~nm}$. Therewith, the curve slope was straighter when the flow was cooled. Thus, in the experiments, the aerosol flow was humidified to $100 \%$ at 30 and $10{ }^{\circ} \mathrm{C}$. Meanwhile, the flow is enriched in water molecules more effectively at higher temperature

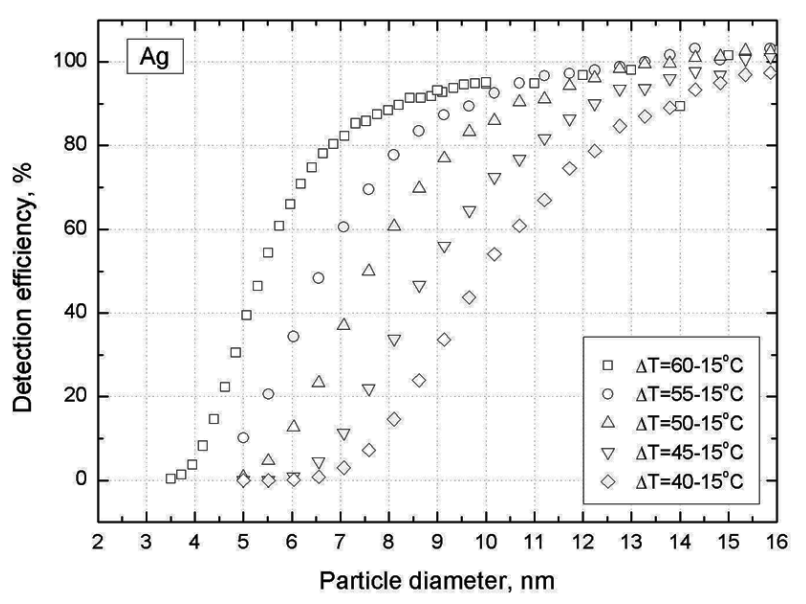

Fig. 2. Detection efficiencies of the TSI CPC 3785 as a function of the particle size using constant temperature $\left(15^{\circ} \mathrm{C}\right)$ of the saturator and different temperatures of the growth tube. 
of the saturator. However, the determined cut-size was smaller under lower temperature. It seems that the temperature difference between the growth tube and the saturator has a larger effect on the cut-size than the humidifying of aerosol in the saturator.

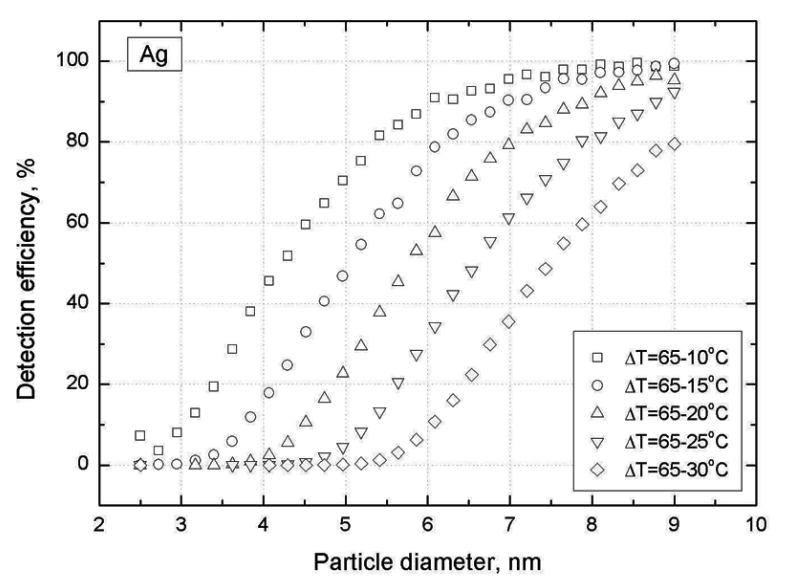

Fig. 3. Detection efficiency of the TSI CPC 3785 as a function of the particle size using constant temperature $\left(65^{\circ} \mathrm{C}\right)$ of the growth tube and different temperatures of the saturator.

\subsection{Cut-size determination methods in the default regime of water-based $C P C$}

In order to determine the instrument cut-sizes, different fitting methods to the experimental data are used. We compared the three used methods and selected one method to calculate the instrument cutsizes. Thus, we determined the detection efficiency of CPC experimentally. The experiment was performed for silver particles from 2 to $10 \mathrm{~nm}$ in diameter. It is the range where there are all interesting cutsizes of the most CPCs. The CPC was operated with the saturator temperature of $20^{\circ} \mathrm{C}$ and the growth tube temperature of $60{ }^{\circ} \mathrm{C}$. The experimental data in Fig. 4 show that detection efficiency approached $100 \%$ for particles larger than $8.1 \mathrm{~nm}$. For particles smaller than $6.1 \mathrm{~nm}$, the detection efficiency was less than $90 \%$. Detection efficiency decreased rapidly with the size decreasing below this value and it was below $10 \%$ for the particles smaller than $3.5 \mathrm{~nm}$ in diameter. All four different equations presented above in Section 2, i. e. four-parameter Mertes's equation [13], three-parameter Hering's equation [10], two-parameter Stolzenburg's equation [i [], and simplified Mordas's equation [18], were fitted to the experimental detection efficiency data using the least squares method. The free parameters were obtained separately for each case. The results are presented in Fig. 4. It shows that the fitting by Stolzenburg's and Mordas's equations has the best overall agreement with the experimental data. The fitting by the Hering's method showed a good agreement for larger particles than for smaller ones. On the contrary, the Mertes's method has a better agreement for smaller particle. The Stolzenburg's and Mordas's methods did not indicate a large difference. However, the slopes of both fittings are not the same. Compared with other fittings, the Mordas's equation gets into the average of all fittings. Thus, we selected Mordas's method to describe the detection efficiency of the water-based condensation particle counter and to calculate the instrument cut-sizes in further investigations.

\subsection{Cut-sizes in different operation regimes}

The key parameters determining the instrument detection efficiency are the temperature of the growth tube and the temperature of the saturator. The change of each of them has influence on the supersaturation region inside the TSI CPC 3785. As a result, the changes of the detection efficiency of the CPC were observed. Thus, we did a series of experiments using different temperatures of the growth tube and of the saturator. The growth tube temperature $\left(T_{\mathrm{gt}}\right)$ was changed from 40 to $65^{\circ} \mathrm{C}$ and the temperature of the saturator $\left(T_{s}\right)$ was scanned from 10 to $30^{\circ} \mathrm{C}$.

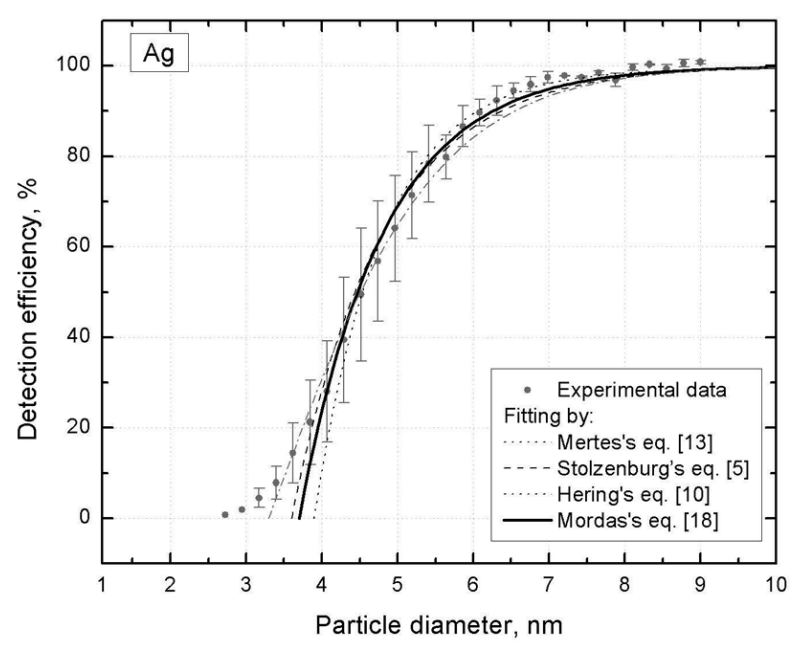

Fig. 4. Comparison of four different fittings to determine the cut-sizes $D_{50 \%}$. 
The temperatures were changed by steps of 5 degrees Celsius. Using the calibration set-up illustrated in Fig. 1, the detection efficiencies were determined for all temperatures. Having the selected fitting equation from the comparison of different fitting methods, the experimental data were fitted and the instrument cut-size $D_{50 \%}$ was calculated. The results of a series of experiments are presented in Table. The results allow selecting the needed operation regime of the waterbased CPC and using it for scientific studies. In this table, the collected data of a wide temperature range of the growth tube and of the saturator are presented. The instrument was operated under normal room conditions when the aerosol flow temperature was $20{ }^{\circ} \mathrm{C}$. Thus, it was enough to heat only the growth tube. Therewith, the cut-size varied from 5.7 to $10.2 \mathrm{~nm}$. During the experiment, the situation when the full instrument was heated was also simulated. As a result, the instrument could not fix a low temperature of the saturator. The saturator temperature fluctuated all the time, changing the detection efficiency. A similar situation was observed at the monitoring stations of small room, where the temperature of the air inside the building increased to $25-30{ }^{\circ} \mathrm{C}$. As a result, the measurement data were chaotic and had no meaning. Thus, we carried out a series of experiments when the saturator temperature could be fixed at 25 and 30 degrees Celsius. Therewith, the used cut-sizes could be selected from 6.4 to $14.6 \mathrm{~nm}$. Moreover, we did a series of experiments increasing the temperature difference between the growth tube and the saturator. In these experiments, the incoming flow was cooled and humidified at a lower temperature. However, we obtained a better detection efficiency of the instrument than in the default regime. So, the cut-size can be decreased from 5.9 to $4.2 \mathrm{~nm}$. Surely, under these operation conditions, the instrument can work only in the laboratory with a constant environment temperature and at a flow temperature lower than $20^{\circ} \mathrm{C}$. Anyway, the $\mathrm{CPC}$ can be used for special experiments and it can change the ultrafine TSI CPC 3786 in some cases.

\subsection{Comparison of the TSI CPC 3785 with the ultrafine TSI CPC 3786}

We compared the detection efficiency of the TSI CPC 3785 and the ultrafine TSI CPC 3786. The performance characteristics of the ultrafine CPC were studied by Mordas et al. [18]. In this study, we made a comparison of both CPCs. The data of the comparison are illustrated in Fig. 5. It shows that the optimised TSI CPC 3785 can detect smaller particles than the ultrafine CPC in the default regime. So, the cut-sizes are 4.2 and $4.6 \mathrm{~nm}$, accordingly. However, the curve slope of detection efficiency is different. As it is seen in Fig. 5, the slope is straighter for the ultrafine CPC. Therefore, if the particle size is smaller than the cut-size $(4.2 \mathrm{~nm})$, the particles are detected with higher efficiency using a simple CPC, but the larger ones with the ultrafine CPC. It can be explained by the formation of the supersaturated region under different conditions. The ultrafine $\mathrm{CPC}$ is operated with the growth tube temperature of $75^{\circ} \mathrm{C}$ and the saturator temperature of $12{ }^{\circ} \mathrm{C}$. Also, the ultrafine instrument has a better aerosol sampling inlet and, as a result, diffusion losses of the smallest particles are lower. Besides, the aerosol particles enter the growth tube at the centreline. Around it, there is clean and humidified sheath air. Thus, the particles pass the supersaturated region exactly at the centreline where the supersaturation values are the highest. Compared with the simple TSI CPC 3785, there is no sheath air in it and the aerosol flow uses the full volume of the growth tube. As a result, the aerosol particles pass the supersaturation region in different locations and their subsequent growth is different. Thus, the detection efficiency curve is straighter in

Table. Determined cut-sizes $(\mathrm{nm}) D_{50 \%}$ of the TSI CPC 3785 at different operation regimes.

\begin{tabular}{c|c|c|c|c|c}
\hline \multirow{2}{*}{$\begin{array}{c}\text { Temperature } \\
\text { of the growth tube, }{ }^{\circ} \mathrm{C}\end{array}$} & \multicolumn{7}{c}{ Temperature of the saturator, ${ }^{\circ} \mathrm{C}$} \\
\cline { 2 - 6 } & 10 & 15 & 20 & 25 & 30 \\
\hline 65 & 4.2 & 5.0 & 5.7 & 6.4 & 7.4 \\
\hline 60 & 4.9 & 5.3 & 5.9 & 8.4 & 10.0 \\
\hline 55 & 5.9 & 6.5 & 7.6 & 10.2 & 12.1 \\
\hline 50 & 6.7 & 7.6 & 8.9 & 12.1 & 14.6 \\
\hline 45 & 7.5 & 8.9 & 10.3 & & \\
\hline 40 & 8.6 & 10.0 & & & \\
\hline
\end{tabular}




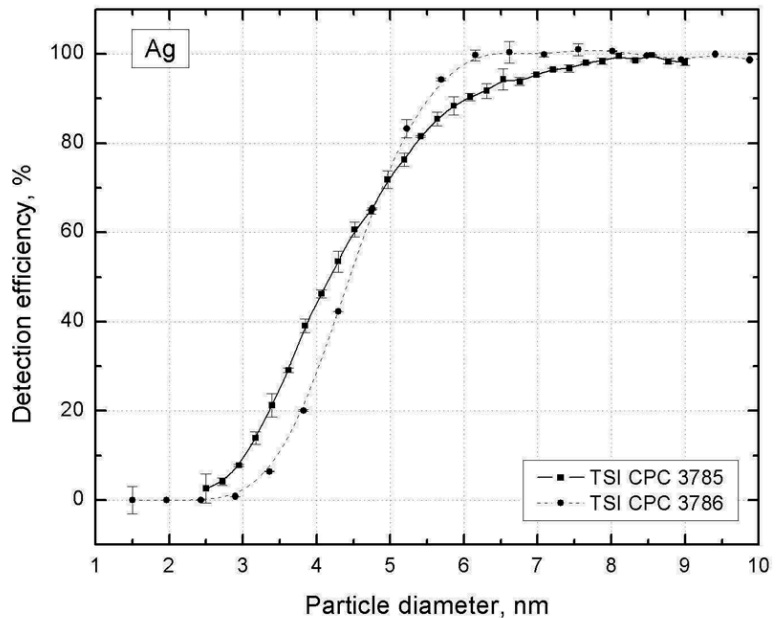

Fig. 5. Comparison of the detection efficiency of the TSI CPC 3785 and the ultrafine TSI CPC 3786.

the ultrafine CPC than in the simple CPC. Nevertheless, the simple CPC can change the ultrafine one in many applications [20].

\section{Conclusions}

The performance characteristics of the TSI CPC 3785 were investigated experimentally. An experimental set-up was developed with the purpose to produce and use the silver aerosol particles of 3-20 nm in diameter. The particle detection efficiency as a function of size was investigated in the default operation regime of the CPC. The operation regime was changed varying the saturator and growth tube temperatures. The influence of temperatures on detection efficiency was studied. The measurements showed that detection efficiency increases when the growth tube temperature increases. With the temperature of the saturator increasing, detection efficiency decreases. The measured detection efficiencies were fitted by four widely used equations. The Mordas's equation was selected and applied to calculate the instrument cut-size $D_{50 \%}$ in the investigation of different operation regimes of the CPC. In the studied regimes, the saturator and growth tube temperatures were varied from 10 to $65^{\circ} \mathrm{C}$. When the saturator temperature was $20^{\circ} \mathrm{C}$ and the growth tube temperature was $60{ }^{\circ} \mathrm{C}$ (default regime), the determined cut-size was $5.9 \mathrm{~nm}$ for the used silver particles. With the saturator temperature increasing, the cut-size increases as well. The cut-sizes were shifted to the smallest sizes increasing the growth tube temperature. The smallest determined cut-size was $4.2 \mathrm{~nm}$ when the saturator temperature was $10^{\circ} \mathrm{C}$ and the growth tube temperature was $65{ }^{\circ} \mathrm{C}$. Working in this operation regime, the TSI CPC 3785 was compared with the ultrafine TSI CPC 3786 in the default regime. The results showed that the determined cut-size $D_{50 \%}$ was $4.2 \mathrm{~nm}$ for the TSI CPC 3785 and $4.6 \mathrm{~nm}$ for the TSI CPC 3786. However, the slope of the detection efficiency curve was straighter for the ultrafine CPC. Thus, the studied CPCs can be used in various applications. For the application purpose, the instrument operation regimes can be easily changed by selecting the needed temperatures. The prepared cut-size in Table allows choosing an optimal regime of temperatures. In general, the TSI CPC 3785 can compete with the ultrafine TSI CPC 3786.

\section{References}

[1] M. Kulmala, H. Vehkamäki, T. Petäjä, M. Dal Maso, A. Lauri, V.M. Kerminen, W. Birmili, and P.H. McMurry, Formation and growth rates of ultrafine atmospheric particles: a review of observations, J. Aerosol Sci. 35, 143-176 (2004).

[2] M.Z. Jacobson, Strong radioactive heating due to the mixing state of black carbon in atmospheric aerosols, Nature 409, 695-697 (2001).

[3] A. Peters and H.E. Wichmann, Epidemiological evidence on the health effects on ultrafine particles, Epidem. 12, 544-589 (2001).

[4] L. Metnieks and L.W. Pollak, Introduction for Use of Photo-Electric Condensation Nucleus Counters (School of Cosmic Physics, Dublin Institute of Advanced Studies, 1959).

[5] M.R. Stoltzenburg and P.H. McMurry, An ultrafine aerosol condensation nucleus counter, Aerosol Sci. Technol. 14, 48-65 (1991).

[6] R. Mavliev, Turbulent mixing condensation nucleus counter, Atmos. Res. 62, 302-314 (2002).

[7] P.H. McMurry, The history of CPCs, Aerosol Sci. Technol. 33, 297-322 (2000).

[8] G.J. Sem, Design and performance characteristics of three continuous-flow condensation particle counters: a summary, Atmos. Res. 62, 267-294 (2002).

[9] G. Mordas, M. Kulmala, T. Petäjä, P.P. Aalto, V. Matulevicius, V. Grigoraitis, V. Ulevicius, V. Grauslys, A. Ukkonen, and K. Hämeri, Design and performance characteristics of a condensation particle counter UF-02proto, Boreal Env. Res. 10, 543-552 (2005).

[10] S.V. Hering and M.R. Stolzenburg, A method for particle size amplification by water condensation 
in a laminar, thermally diffusive flow, Aerosol Sci. Technol. 39, 428-436 (2005).

[11]TSI Inc, Model 3785 Ultrafine Water-based Condensation Particle Counter, Operation and Service Manual, P/N 1930072, Revision B (TSI press, Massachusetts, 2005).

[12]H.G. Scheibel and J. Porstendörfer, Generation of monodisperse Ag- and $\mathrm{NaCl}$-aerosols with particle diameters between 2 and $300 \mathrm{~nm}$, J. Aerosol Sci. 14(2), 113-126 (1983).

[13]S. Mertes, F. Schröder, and A. Wiedensohler, The particle detection efficiency curve of the TSI-3010 $\mathrm{CPC}$ as a function of the temperature difference between saturator and condenser, Aerosol Sci. Technol. 23, 257-261 (1995).

[14] A. Wiedensohler, D. Orsini, D.S. Covert, D. Coffmann, W. Cantrell, M. Havlicek, F.J. Brechtel, L.M. Russell, R.J. Weber, J. Gras, J.G. Hudson, and M. Litchy, Intercomparison study of the size-dependent counting efficiency of 26 condensation particle counters, Aerosol Sci. Technol. 27, 224-242 (1997).

[15]D.F. Banse, K. Esfeld, M. Hermann, B. Sierau, and A. Wiedensohler, Particle counting efficiency of the TSI CPC 3762 for different operation parameters, J. Aerosol Sci. 32, 157-161 (2001).

[16]K. Hämeri, I.K. Koponen, P.P. Aalto, and M. Kulmala, The particle detection efficiency of the TSI-3007 condensation particle counter, J. Aerosol Sci. 33, 1463-1469 (2002).

[17]T. Petäjä, G. Mordas, H. Manninen, P.P. Aalto, K. Hämeri, and M. Kulmala, Detection efficiency of water-based TSI condensation particle counter 3785, Aerosol Sci. Technol. 40, 1090-1097 (2006).

[18] G. Mordas, H.E. Manninen, T. Petäjä, P.P. Aalto, K. Hämeri, and M. Kulmala, On operation of the ultra-fine water-based CPC TSI3786 and comparison with other TSI models (TSI3776, TSI3772, TSI3025, TSI3010, TSI3007), Aerosol Sci. Technol. 42, 152-158 (2008).

[19]S.V. Hering, M.R. Stolzenburg, F.R. Quant, D.R. Oberreit, and P.B. Keady, A laminar-flow, water-based condensation particle counter (WCPC), Aerosol Sci. Technol. 39, 659-672 (2005).

[20] S. Biswas, P.M. Fine, M.D. Geller, S.V. Hering, and C. Sioutas, Performance evaluation of a recently developed water-based condensation particle counter, Aerosol Sci. Technol. 39, 419-427 (2005).

\title{
VANDENS KONDENSACINIO DALELIŲ SKAITIKLIO DARBO REŽIMO OPTIMIZAVIMAS
}

\author{
G. Mordas ${ }^{a}$, T. Petäjä ${ }^{b}$, V. Ulevičius ${ }^{a}$ \\ ${ }^{a}$ Valstybinis moksliniu tyrimu institutas Fiziniu ir technologijos mokslu centras, Vilnius, Lietuva \\ ${ }^{\mathrm{b}}$ Helsinkio universiteto Fiziniu mokslu fakultetas, Helsinkis, Suomija
}

\section{Santrauka}

Kondensacinis dalelių skaitiklis TSI 3785 yra naujas žingsnis ultrasmulkiụjų aerozolio dalelių matavimo technikoje. Straipsnyje pateikiami šio skaitiklio eksperimentinių tyrimų duomenys. Ivertintas aerozolio dalelių registravimo efektyvumas kaip dalelių dydžio funkcija, garų prisotinimo ir aerozolio dalelių augimo kamerose naudojant skirtingą temperatūrą. Nustatyta, kad daleliu registravimo efektyvumas gali būti pagerintas didinant dalelių augimo kameroje temperatūrą ir mažinant temperatūrą garų prisotinimo kameroje. Eksperimentiškai nustatytos registravimo efektyvumo vertės buvo aprašytos dviejų laisvų parametrų funkcija ir ją taikant buvo įvertinti registravimo efektyvumo ribiniai dydžiai $\left(D_{50 \%}\right)$. Ribiniai dydžiai paklaidų ribose sutampa su dydžiais, nustatytais naudojant kitas metodikas. Registravimo ribiniai dydžiai buvo ìvertinti naudojant garu prisotinimo ir daleliu augimo kamerose skirtingas temperatūras. Eksperimento metu daleliu augimo kameroje temperatūra buvo kečiama nuo $40 \mathrm{iki}$ $65^{\circ} \mathrm{C}$, o garų prisotinimo kameroje - nuo 10 iki $30^{\circ} \mathrm{C}$. Mažiausias nustatytas registravimo ribinis dydis buvo $4,2 \mathrm{~nm}$, o didžiausias - $14,6 \mathrm{~nm}$. Gamintojo nustatytame veikimo režime sidabro dalelèms ribinis dydis yra $5,9 \mathrm{~nm}$. Tiriamo TSI 3785 kondensacinio dalelių skaitiklio registravimo efektyvumas buvo palygintas su kito, itin smulkias daleles registruojančio, kondensacinio skaitiklio TSI 3786 efektyvumu. Eksperimento rezultatai parodè, kad testuojamo TSI 3785 prietaiso veikimo režimas gali būti optimizuotas ir turèti mažesnę ribinio dydžio vertę $(4,2 \mathrm{~nm})$ nei itin smulkių dalelių skaitiklis TSI $3786(4,6 \mathrm{~nm})$, dirbantis gamintojo nustatytame veikimo režime. 